\title{
An Overview of Ecosystem Service Studies in a Tropical Biodiversity Hotspot, Sri Lanka: Key Perspectives for Future Research
}

\author{
Chaya Sarathchandra 1,2 (D), Yirga Alemu Abebe ${ }^{3,4}\left(\mathbb{D}\right.$, Iresha Lakmali Wijerathne ${ }^{2}$, \\ Sasith Tharanga Aluthwattha ${ }^{5,6} \mathbb{D}$, Sriyani Wickramasinghe ${ }^{2}$ and Zhiyun Ouyang ${ }^{1, * \mathbb{D}}$
}

1 Research Center for Eco-Environmental Sciences, State Key Laboratory of Urban and Regional Ecology, Chinese Academy of Sciences, Beijing 100085, China; chaya@rcees.ac.cn

2 Department of Biological Science, Faculty of Applied Sciences, Rajarata University of Sri Lanka, Mihintale 50300, Sri Lanka; ireshawijerathne1990@gmail.com (I.L.W.); sriwick@gmail.com (S.W.)

3 State Key Laboratory of Super Lattices and Microstructures, Institute of Semiconductors, Chinese Academy of Sciences, Beijing 100083, China; yirgaalemu@semi.ac.cn

4 Department of Electrical and computer engineering, Faculty of Electrical Engineering, Institute of Technology, Hawassa University, Hawassa P.O. Box 05, Ethiopia

5 Guangxi Key Laboratory of Forest Ecology and Conservation, College of Forestry, Guangxi University, Daxuedonglu 100, Nanning 530004, China; aluthwattha@yahoo.com

6 State Key Laboratory of Conservation and Utilization of Subtropical Agro-bioresources, College of Forestry, Guangxi University, Daxuedonglu 100, Nanning 530004, China

* Correspondence: zyouyang@rcees.ac.cn; Tel.: +86-13910780501

check for updates

Citation: Sarathchandra, C.; Abebe, Y.A.; Wijerathne, I.L.; Aluthwattha, S.T.; Wickramasinghe, S.; Ouyang, Z. An Overview of Ecosystem Service Studies in a Tropical Biodiversity Hotspot, Sri Lanka: Key Perspectives for Future Research. Forests 2021, 12, 540. https://doi.org/10.3390/ f12050540

Received: 11 March 2021

Accepted: 21 April 2021

Published: 27 April 2021

Publisher's Note: MDPI stays neutral with regard to jurisdictional claims in published maps and institutional affiliations.

Copyright: (c) 2021 by the authors. Licensee MDPI, Basel, Switzerland. This article is an open access article distributed under the terms and conditions of the Creative Commons Attribution (CC BY) license (https:/ / creativecommons.org/licenses/by/ $4.0 /)$.

\begin{abstract}
Tropical island countries are often highly populated and deliver immense ecosystem service benefits. As human wellbeing depends on these ecosystems, proper management is crucial in the resource-rich tropical lands where there is less related research. Though ecosystem service and biodiversity studies are a promising path to inform the ecosystem management for these mostly developing countries, published evidence of using ecosystem service studies in decision making is lacking. The purpose of this study is to provide an overview of ecosystem services and related research in Sri Lanka, examining trends and gaps in how these studies are conceptualized. Out of the considered 220 peer-reviewed articles, the majority of articles (48.2\%) were terrestrial and forest related while coastal ecosystems were considered in $33.2 \%$ of studies. In most studies, the ecosystem service category studied was provisioning (31.5\%) followed by regulatory service $(28.7 \%)$. Studies investigating and quantifying ecosystem services, pressures on ecosystems, and their management were fewer compared to studies related to biodiversity or species introduction. Moreover, studies investigating the value of ecosystem services and biodiversity to the communities or involvement of stakeholders in the development of management actions regarding the ecosystem services were rare in Sri Lanka, and an intense focus from future studies in these aspects is timely and necessary.
\end{abstract}

Keywords: ecosystem services; biodiversity hotspot; Sri Lanka; forest; coastal ecosystems; management; policy

\section{Introduction}

Ecosystem services are identified as the benefits people receive from nature, such as climate regulation, food and clean water provision, spiritual, recreational, and cultural benefits, and supporting services such as nutrient cycling, which are intermingled to provide and maintain the conditions for life on earth [1-4]. Resource-rich tropical islands such as Sri Lanka provide immense ecosystem service benefits to their dwellers. As human wellbeing depends on ecosystems and ecosystem services, requiring an understanding of the provision and management of ecosystem services is crucial to developing countries in the tropics where very few ecosystem service studies have been conducted compared 
to other countries. The tropics are recording increasing population and anthropogenic activities, thus imposing immense pressure on ecosystems. Ecosystem service and biodiversity studies are a promising path to inform the ecosystem management of these tropical countries. Still, there is a lack of understanding or encouragement towards better management of ecosystems among stakeholders, including the public and decision makers, on the values of nature which are sustained from healthy ecosystems and how they affect life on earth, leading to disastrous decisions in terms of ecosystems. Biodiversity loss and habitat degradation pose serious threats to natural habitats and ecosystem services [5-9] Therefore, studying and measuring ecosystem services and assigning accurate values for provided services are crucial to understand the links between each component of the system and to inform the consequent impacts if the balance between them is disturbed. Mapping and documenting ecosystem services is essential to understand how ecosystems contribute to human wellbeing and to support policies that have an impact on natural resources [10], as biodiversity loss and ecosystem damage is occurring at an unprecedented rate and is having a negative impact on human livelihoods. Information on ecosystem services can help to communicate the value of nature to decision makers with the hope of reversing this trend [3].

During the past few decades, global land cover has changed faster than the past few centuries, posing great impacts on ecosystem services [11]. Tropical forests host at least two-thirds of the terrestrial ecosystem biodiversity and, from the local to the global level, provide significant benefits to humans through the provision of economic goods and ecosystem services [12,13]. Yet, tropical forests worldwide are subject to high rates of deforestation and degradation with an estimate of 17 million ha or $1 \%$ of total forest area removed per year [11], with the growth of population and increasing demands for ecosystem products placing much pressure on the fragmented secondary as well as primary forests. Agricultural expansion itself has cleared $27 \%$ of the tropical forest biomes already [14].

Here we selected a tropical island nation, Sri Lanka, for the current study to understand key perspectives for future ecosystem service research. Despite the size of the island is $65,625 \mathrm{~km}^{2}$, Sri Lanka has a high level of ecosystem and biological diversity. A wide range of natural ecosystems such as lowland rainforests, tropical montane forests, dry mixed-evergreen forests, grasslands, mangroves, and estuaries house an enormous amount of biodiversity [15].

As a part of a global biodiversity hotspot, Sri Lanka plays a major role in harboring and preserving unique biodiversity. Despite the collective importance of the Western Ghats-Sri Lanka hotspot, the island Sri Lanka has some exceptional biodiversity that differs from the Ghats and southern India. For example, clad level diversity of several invertebrates and vertebrates is unique in the island [16], while many of the invertebrates in Sri Lanka are yet to be studied. Sri Lanka so far has had about 3350 species of flowering plants described, of which about $23 \%$ are endemic, and more than $50 \%$ of invertebrates and vertebrates such as fish and frogs are endemic [16]. However, $94 \%$ of endemic angiosperms and the majority of endemic vertebrates and invertebrates are confined to the wet zones, wet evergreen and wet montane forests of the southwest and south-central regions of the island, which is only about $7500 \mathrm{~km}^{2}[17,18]$.

Habitable environments all over the island with favorable climatic conditions, relatively high rainfall, and yearlong sunshine, along with fertile soils and historical and modern irrigation systems, have provided an abundant supply of food to the population which was later extended into various types of plantation agriculture $[19,20]$. Sri Lanka is also abundant in numerous natural resources such as graphite, gems, high purity silica quartz, and marine resources [21,22].

A rising population and parallel increment of agricultural production and industrialization in recent decades have indiscriminately exploited many of these ecosystems for commercial, agricultural, residential, and industrial development and waste dumping [23,24], along with climate change [20]. The colonial era of Sri Lanka (1800-1950 began 
with the clearing of many natural ecosystems for economic plantations such as tea and rubber [25] thus eventually depleting the ecosystems, biodiversity, and ecosystem services they used to provide. The early 19th century triggered this by the drastic changes in the new land-use policies. Since then, deforestation caused by unplanned developmental activities has become an inherent phenomenon in Sri Lanka [26]. Sri Lanka had a forest cover of $80 \%$ in the 1800 s, which was reduced to $25 \%$ by 2010 [27].

Though Sri Lanka is a relatively large island country full of natural resources, studies assessing them as the ecosystem services they provide are rare. Sri Lanka recorded a $28.7 \%$ forest cover at the start of last decade [28], terrestrial protected area coverage was $29.86 \%$ [29] in 2015, and the coastal area consists of $25 \%$ of the total land [30]. At present, though some reports state Sri Lanka has 16.5\% forest cover [31], no published data support this claim. Recent years have recorded the worst forest cover clearing due to infrastructure development activities in Sri Lanka [32], in addition to illegal logging activities recorded throughout the country, though the country has suspended any form of commercial timber extraction [33]. Considering the intensity of resource and environmental degradation and exploitation occurring in the country, it is essential to assess the ecosystem services for better planning of resource utilization and sustainable development.

Therefore, in this period where the majority of terrestrial and coastal ecosystems are being cleared, it is timely to study and gather information on the status of natural ecosystems in order to safeguard the valuable services they provide, as most of the rural population depends directly on them for food, water, and numerous livelihoods. Although specific ecosystems such as mangroves have been extensively assessed in Sri Lanka [34] there is a huge gap of studies on many ecosystems, ecosystem services, and biodiversity in Sri Lanka. The main aim of this study is to emphasize the gaps in the island-wide ecosystem service studies. Therefore, the major objective of this review was to assess the current condition and trends of ecosystem service studies in Sri Lanka and to explore the future management scenarios of ecosystem services in Sri Lanka with the empowerment of local stakeholders.

\section{Materials and Methods}

\subsection{Defining Ecosystem Services and Terminology}

For this study we defined ecosystem services as the benefits people receive from ecosystems. We considered both direct and indirect services provided by ecosystems under the four categories of: cultural ecosystem services (nonmaterial benefits such as recreational activities, aesthetic values); provisioning ecosystem services (products obtained from ecosystems); regulating ecosystem services (the benefits obtained from the regulation of ecosystem processes); and supporting ecosystem services [2]. Thus, we included papers that considered:

- the importance of biodiversity in the delivery of ecosystem services;

- impact of anthropogenic and natural drivers of change on ecosystem services;

- market and non-market values of ecosystem services;

- traditional knowledge, stakeholder perceptions on ecosystem services;

- management of ecosystem services.

\subsection{Literature Collection, Eligibility and Exclusion Criteria}

For identifying publications related to ecosystem services and biodiversity studies in Sri Lanka, we searched ISI Web of Science (WOS: Clarivate Analytics, Philadelphia, PA, USA) for articles published between 1988 and 2020 and Scopus (https:/ /www.scopus.com/ (accessed on 20 March 2021)) for articles published between 1992 and 2020. We last accessed these databases in March 2021 and used the following search terms:

- For all available databases of WOS (from 1988 to 2021),

1. TOPIC: ("Sri Lanka*" AND "ecosystem service*") $\rightarrow 79$ results

2. TOPIC: ("Sri Lanka*" AND "biodiversity*") $\rightarrow 502$ results 
- For the Scopus database, for title, abstract and keywords (from 1992 to 2021),

3. TITLE-ABS-KEY ("Sri Lanka*" AND "ecosystem service" $\left.{ }^{* \prime}\right) \rightarrow 78$ results

4. TITLE-ABS-KEY ("Sri Lanka*" AND "biodiversity") $\rightarrow 355$ results

We are aware that there might be publications covering similar issues that do not use the terms "ecosystem services" or "biodiversity". However, the keywords used in the search strings were designed to capture related articles as much as possible and to keep the study objectives straightforward.

We determined inclusion and exclusion criteria regarding literature type, as only journal articles were selected. We excluded book series, books, chapters in book and conference proceedings. We retained publications that have quantified one or more ecosystem services related to any ecosystem type of Sri Lanka. As many Sri Lankan ecosystem and biodiversity research is unpublished and confined to thesis studies, we did not include them in this review as we could not get access to them during the review period. With regards to timeline, we tried to select articles published from 1988 as we wanted to see the evolution of research related to ecosystem services and biodiversity in Sri Lanka; however, the Scopus database is limited to publication information from 1992 onwards.

\subsection{Systematic Review Process}

We screened a total of 1014 articles from both WOS and Scopus using the title, abstract and keywords of each study and excluded 501 of them from further checking based on their geographical irrelevance (Supplementary File S1). Then we explored the remaining 513 articles in detail, checking the methods. We classified these articles in to two categories: ecosystem services studies and biodiversity studies. Studies that only mentioned ecosystem benefits but that did not quantify, value them or measure threats and pressures on ecosystems or biodiversity and did not discuss any issues related to ecosystem and biodiversity management were not included as we were interested in the body of literature that actively deems itself as ecosystem service and related biodiversity research in Sri Lanka. We further removed papers that did not deal with ecosystem services or ecosystem service-related biodiversity aspects and those that only mentioned these two terms in their abstract or keywords and did not identify or discuss any type of ecosystem service or biodiversity studies in the full article [35].

We screened a total of 157 ecosystem service studies from both Scopus and WOS and we eliminated 49 studies because of geographical irrelevance and due to duplication and this left us with 108 ecosystem services studies for a detailed examination. Then we screened 856 biodiversity studies from both Scopus and WOS from which we eliminated 471 studies due to geographical irrelevance and duplication which left us with 385 studies that were related to biodiversity studies in Sri Lanka. We further explored these studies to check the relevancy for the objectives of our study and we eliminated 273 studies due to irrelevance to our study context as these studies focused on taxonomic issues and new species introductions. This left us with 112 biodiversity studies for further analysis.

\subsection{Data Extraction, Establishment of the Database and Analysis}

We extracted data first by reading the titles, then through the abstracts, and finally by in depth exploration of the full article to identify the methods and other details of ecosystem service study. For each selected study, we extracted information on the location of the study, the type and numbers of ecosystem services evaluated, and the methods used to quantify services. Selected articles were reported with the title, authors, journal, and date of publication. Each article was attributed an identification code as first author and date of publication for the feasibility of identification. Furthermore, the geographical and climatic zones of the studies were recorded including the aim of the study, the type of the ecosystem study and the nature of the used data (i.e., primary, secondary, remote sensing, combined). Two categories were considered as primary data (field and participatory). Finally, we recorded the technical methods used for the assessment (GIS, modelling, statistics, valuation, or combined) in each study. 
Patterns across ecosystem service studies, quantification methods, and biodiversity research were evaluated using ggplot2 in R v3.3.1 [36] and maps were created using ArcGIS v.10.6. We used descriptive statistics to calculate the number of publications for each category for the variable identified in the data collection section. Our results are reported as both the total and the relative proportion within the reviewed papers and are represented either as the count/portion of articles that met our objectives. A detailed description of the data that were collected on ecosystem service quantification and information about how the data were collected is listed in the Supporting Information.

\section{Results}

A total of 220 articles met the review criteria stated above and were authored between 1988 and 2021. The majority of the articles were about biodiversity (50.9\%) and were primarily related to species introduction, species abundance richness or changes in biodiversity, and approximately half of studies were related to ecosystem services $(49.1 \%)$. Studies that measured both biodiversity and ES were 19.5\%. The number of papers discussing ecosystem services and biodiversity in Sri Lanka showed a peak in 2020 (Figure 1).

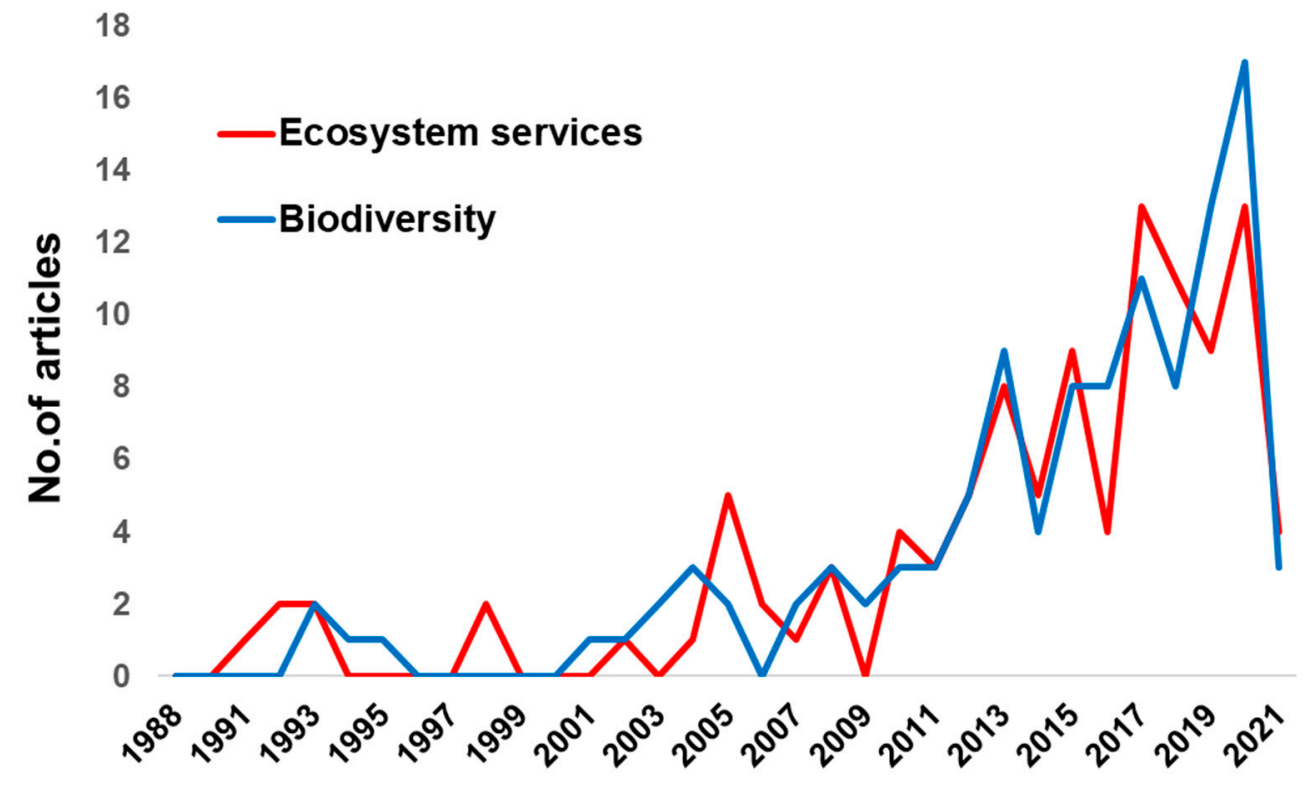

Figure 1. Number of published ecosystem- and biodiversity-related research.

As Sri Lanka can be classified into three distinctive climatic zones, namely wet, intermediate and dry, covering $23 \%, 12 \%$ and $65 \%$, respectively, of the total land area [18], we further checked the study proportion distribution in these three zones. Though dry zone comprises the highest proportion of the total land area, studies conducted in this climatic zone were proportionately low. Within the assessed ecosystem services and biodiversity studies in Sri Lanka, we observed a geographical bias. The selected studies were widely distributed across the wet zone $(56.4 \%)$ followed by the dry zone $(26.5 \%)$ and the intermediate zone (17.1\%) (Figure 2). 


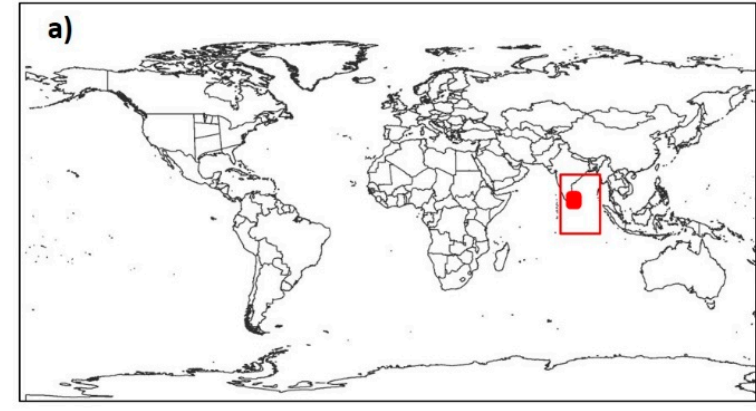

b)

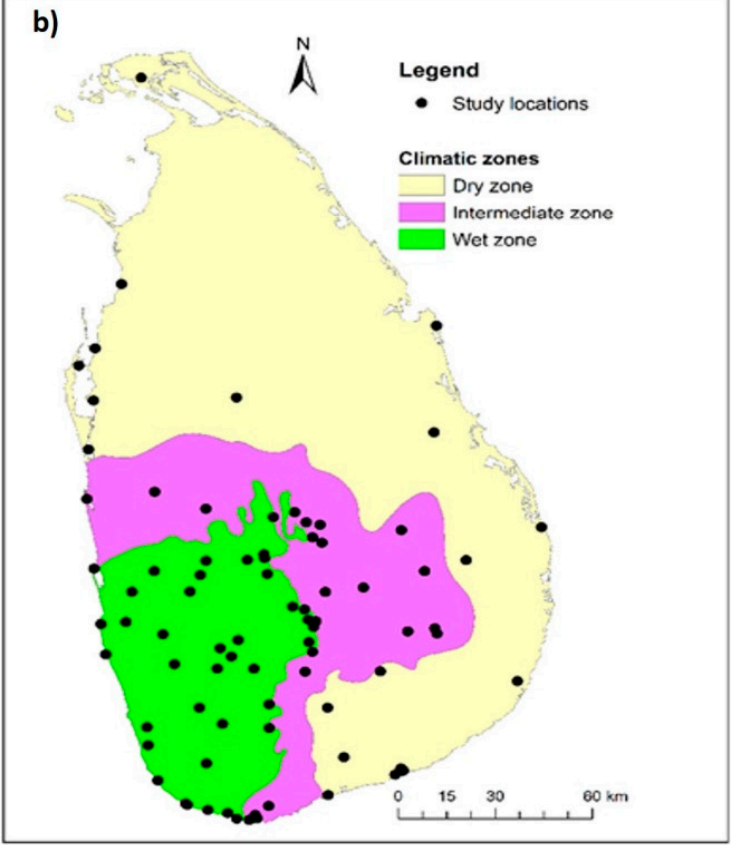

c)

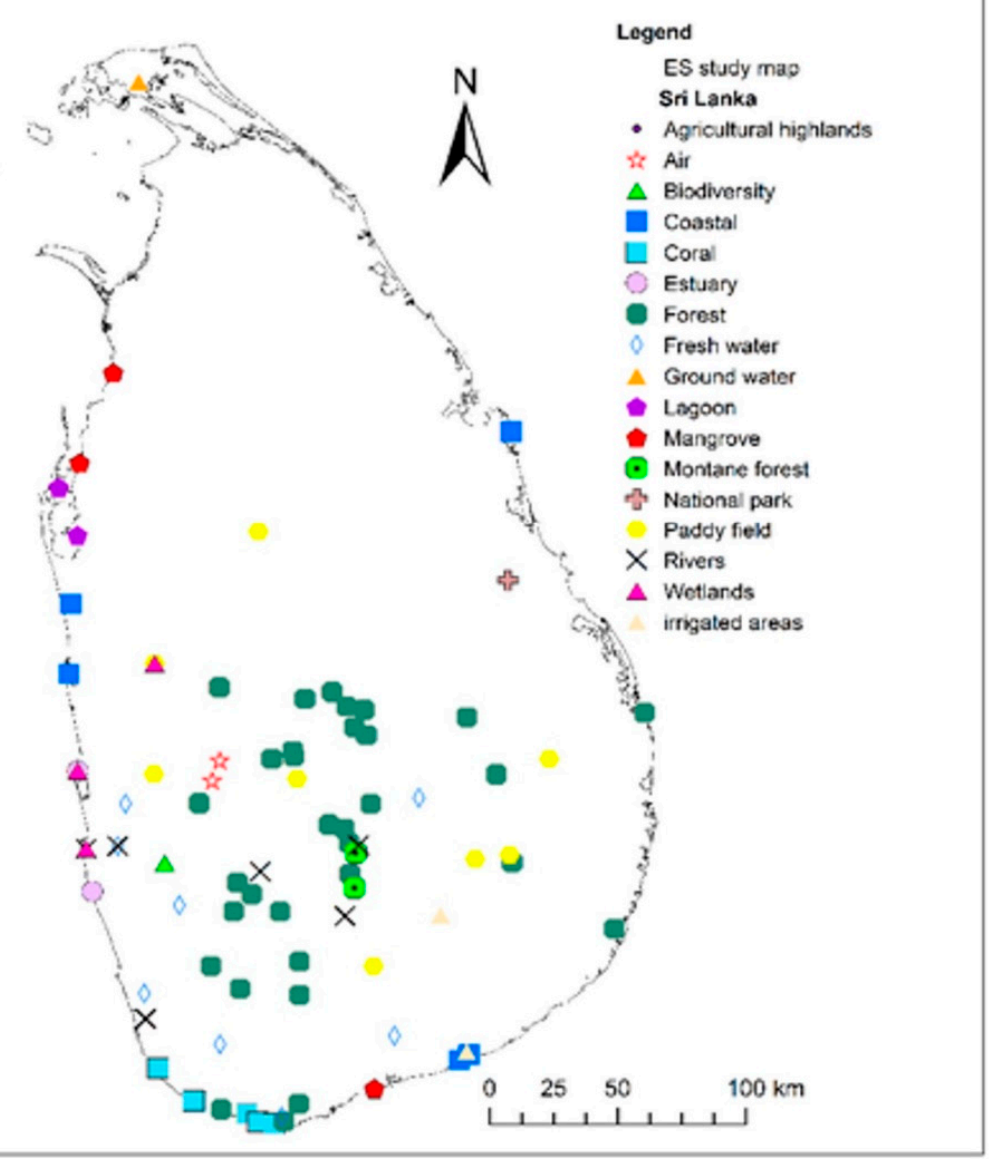

Figure 2. Types and distribution of reviewed ecosystem service and biodiversity studies in Sri Lanka. (a) Location of Sri Lanka in the world map. (b) Study distribution according to the climatic zone (c) Study locations in relation to the ecosystem they were conducted.

The majority of studies were conducted in specific ecosystems while studies investigating more than one type of ecosystem or their interrelatedness, treating the whole country as one ecosystem, were very few [27]. The highest studied ecosystem for any climatic zone was forest ecosystems (34.1\%) followed by coastal ecosystems $(30.9 \%)$ while the lowest studied ecosystem according to the peer-reviewed literature for any climatic zone was urban ecosystems (1.4\%). Though Sri Lanka has a coverage of 19,897 km2 (29.86\%) of terrestrial protected areas [19], the number of published studies that were conducted in protected areas were very limited.

Across the 220 studies, 108 were solely on ecosystem services while 112 were related to biodiversity. We identified 21 unique ecosystem services (Figure 3) investigated in these studies. The most frequently quantified ecosystem services were food supply, fresh water provision, recreational values, carbon storage, nontimber forest products and water quality. While provisioning $(31.5 \%)$ and regulating services $(28.7 \%)$ were quantified most often, cultural $(25.0 \%)$ and supporting ecosystem services $(14.8 \%)$ were less frequently considered. Most studies (85) considered one or two types of ecosystem services and we found that ecosystem services from all possible combinations of these four categories were evaluated together in a lower number (18) of individual studies. 


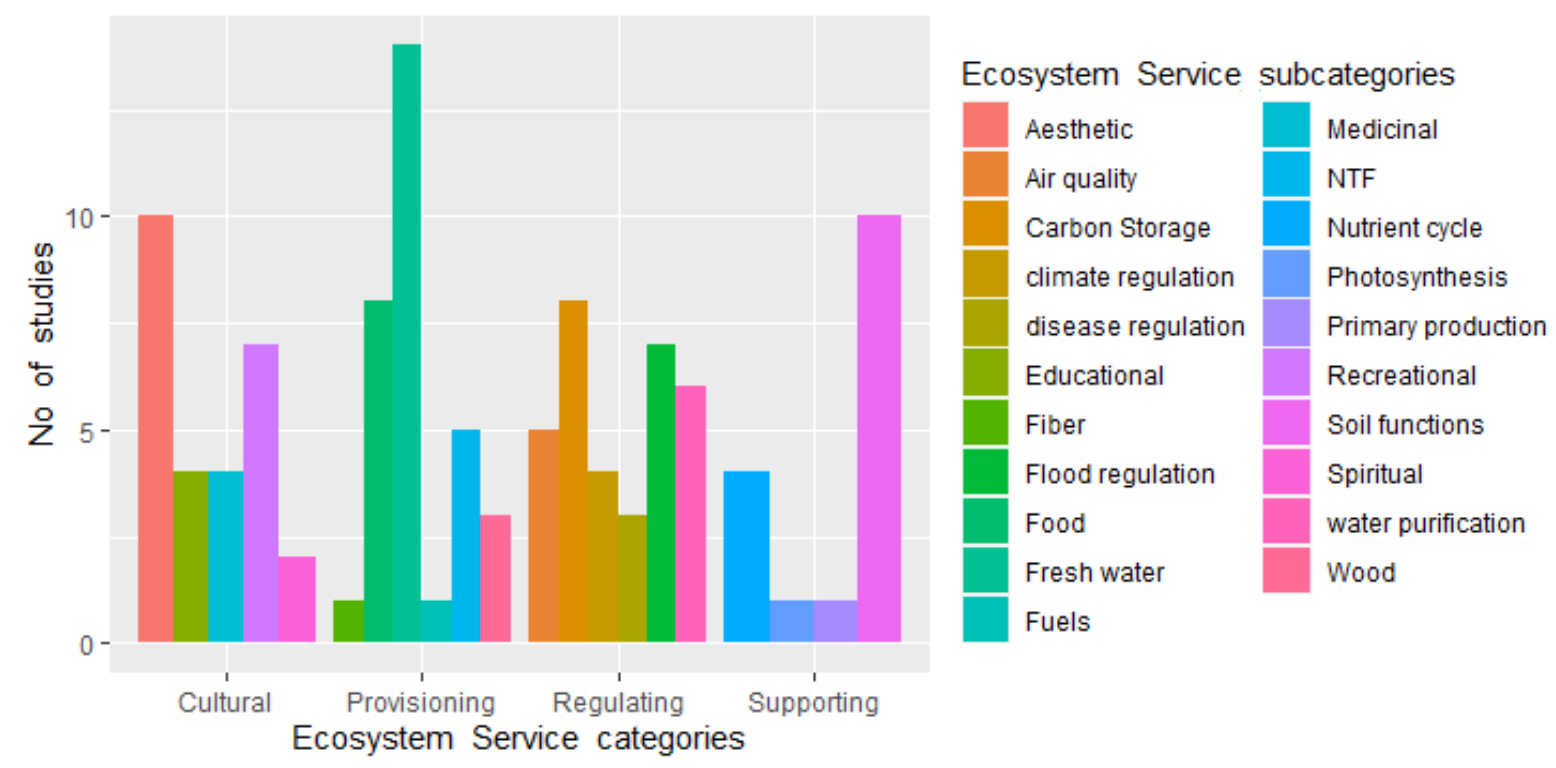

Figure 3. Ecosystem services evaluated among the reviewed studies conducted in Sri Lanka. The 21 types of ecosystem services identified in the studies are listed in the legend according to the definition of the Millennium Ecosystem Assessment [2] and in this graph we omit the studies related to biodiversity.

Analysis of different study types (Figure 4) for the identified ecosystem services and biodiversity studies for each considered ecosystem in Sri Lanka showed that for any given ecosystem the majority of the papers were biodiversity related (forest 38.7\%, coastal 17.6\%, national parks $40 \%$ ) while the least common study type were pressure biodiversity studies (12.3\% in total) while local knowledge and stakeholder involvement was recorded in $14.5 \%$ of studies, biophysical quantification in $17.7 \%$, ecosystem trade-off in $1.4 \%$, and ecosystem valuation studies were $12.7 \%$ in total.

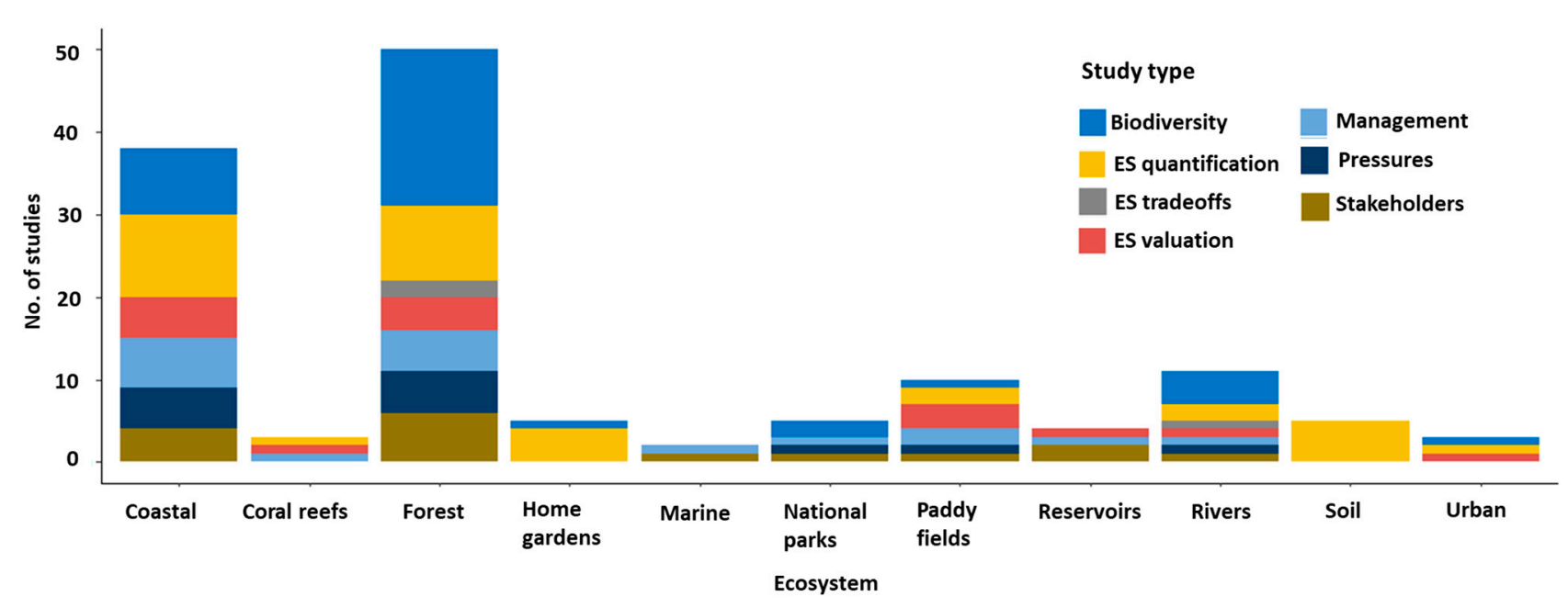

Figure 4. Frequency of different study types for the identified ecosystem services and biodiversity studies in Sri Lanka.

Coastal and forest ecosystems have the highest number of studies related to stakeholders' ecological knowledge or stakeholder participation with $14.7 \%$ and $10.6 \%$, respectively, of all studies in those habitats. In the reviewed literature, agriculture-related ecosystem service research and studies using social science techniques are underrepresented and hardly found. This is a tragic situation for a country that is one of the most ancient agricultural civilizations with tremendous indigenous knowledge on different agricultural systems. 
The more commonly studied pressures on Sri Lankan ecosystem studies were identified as water pollution, habitat loss, and degradation, whilst studies on invasive species were also recorded and considered as pressures on studied ecosystems.

The peer reviewed articles used five types of data sources (Figure 5) in their studies, namely primary, secondary, remote sensing and combined. We categorized primary data as field and participatory data. Any study that used two or more data sources was categorized as combined. We found that remote sensing data were frequently used in studies starting from 2010. The majority of services were quantified using primary data, and from that the highest was field data $(40.0 \%)$ followed by participatory data $(18.6 \%)$, while studies that used some form of secondary data comprised $14.5 \%$ of the total and studies that used remote sensing data comprised $14.1 \%$.

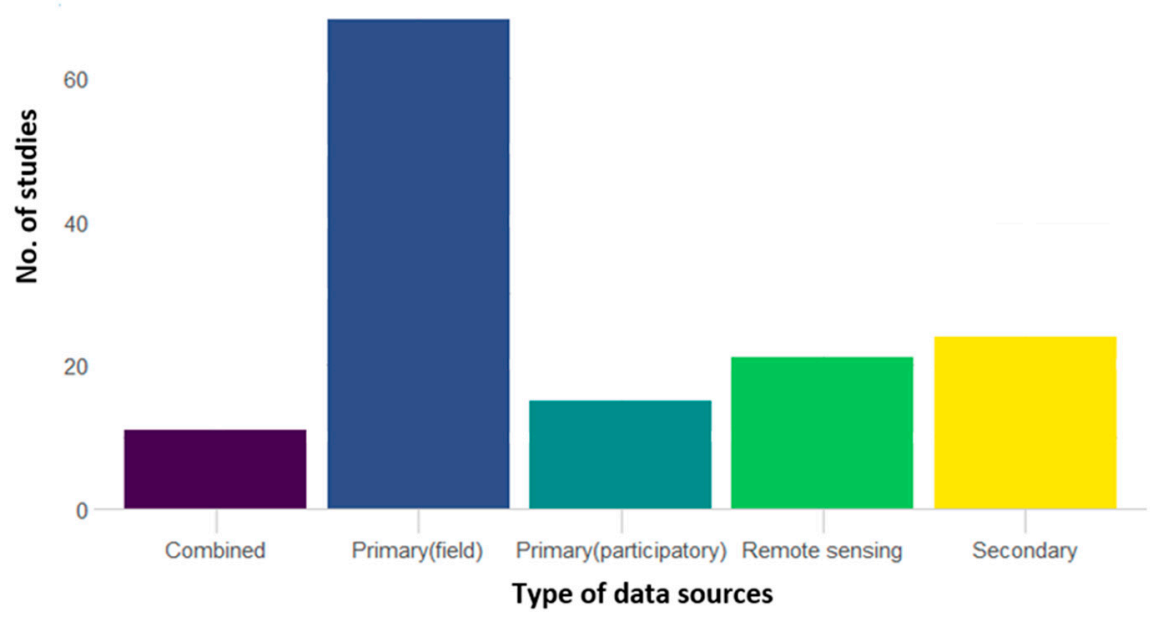

Figure 5. Different types of data sources used in the reviewed studies.

In the studies we assessed, three different groups of technical methods were used to quantify ecosystem services. The most frequently used were GIS and statistical analysis (descriptive or other), followed by various modelling tools and valuation methods (Figure 6).

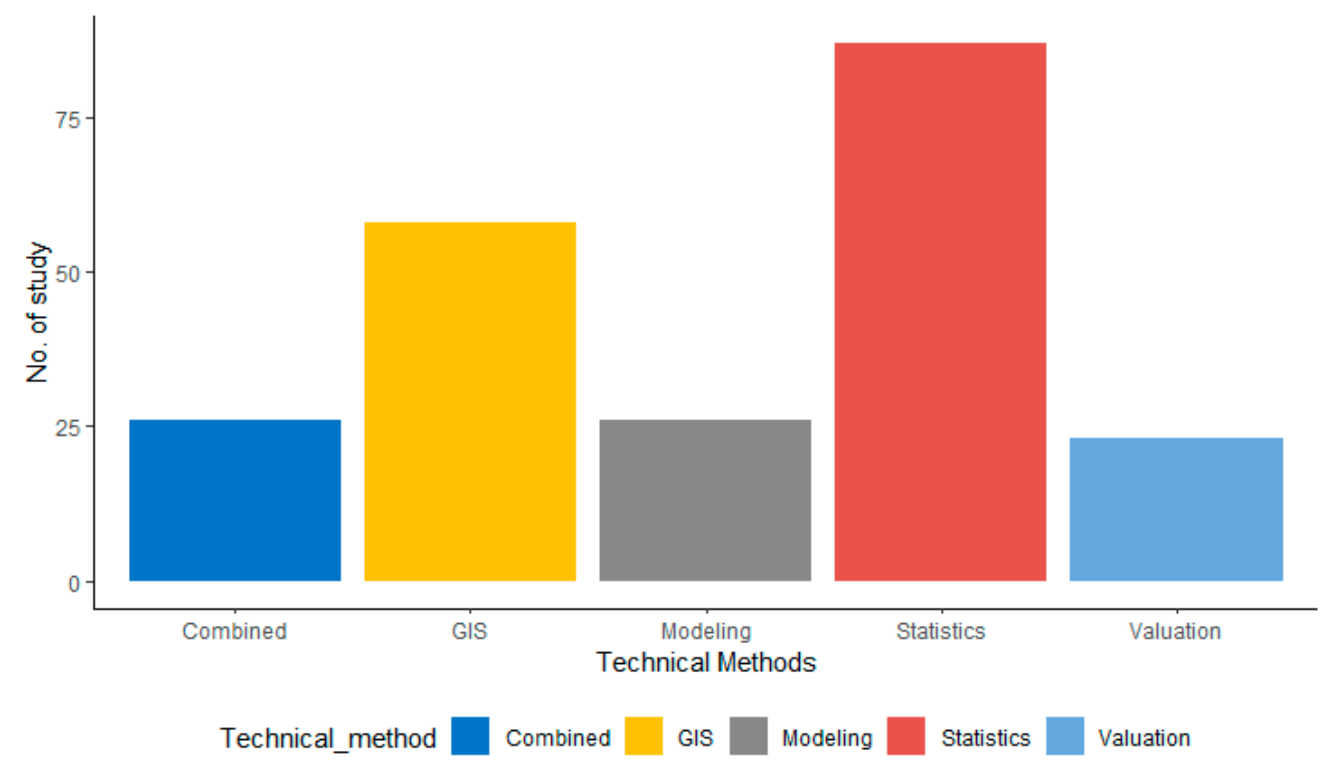

Figure 6. Different groups of technical methods used to quantify ecosystem services. 
However, in the papers where a specific focus was identified, coastal ecosystems were the most frequently considered, with mangroves being the most frequent focus (38 studies) with biophysical assessments or valuation. The studies investigating recreational and eco-tourism were rare (9) and the lowest amount was studies investigating gene pools (7).

\section{Discussion}

Most of the ecosystem services and related biodiversity studies in Sri Lanka are related to coastal, freshwater, or wetland ecosystems and are interdisciplinary in nature, and discussed resources, their utilization, environmental issues, and management options [30,37-50], compared to the number of forest-related interdisciplinary ecosystem service studies [33,51,52]. Sri Lanka has assigned its forests primarily for conservation since 1989 due to their unique biodiversity and significance in the country's economy [34]. Though these forest ecosystems play a vital role in local economies and livelihoods, through provision of traditional food and medicines, a low number of studies are related to those aspects. Most of the forest ecosystem studies are related to biodiversity [53-62].

Limited research associated with terrestrial ecosystem biodiversity and ecosystem services attempted to estimate the composition of income in the peripheral communities from forest products [51,63-65] but a proper assessment of ecosystem services and biodiversity in Sri Lanka's diverse terrestrial ecosystems is lacking. On the other hand, we found some studies related to biodiversity assessments in remote locations of Sri Lanka $[55,57,66]$ but studies covering and discussing the interrelatedness of ecosystem services in all the climatic zones of Sri Lanka were rare or there were none.

Habitat loss and degradation were strongly associated with forest ecosystems, coastal habitats, and to a lower extent with cultivated and freshwater ecosystems. Invasive species and water pollution from agricultural and industrial output were recorded as the drivers mainly in inland water, and studies dealing with erosion were mainly from the forest, river, and coastal habitats.

Even though Sri Lanka has lost an immense amount of forested land since the start of the colonial era, only a few restoration projects have been implemented and very few were scientifically recorded. Among these studies, only one recent study has discussed the potential of restoration projects to be sold as voluntary carbon credits in the international market by focusing on designing and certifying community-based payments for ecosystem services (PES) programs [67]. This kind of research is rare among Sri Lankan ecosystem service and biodiversity studies, but valuation of ecosystems through monetary terms is crucial as it helps to compare ecosystem services to other types of resources and promote the consideration of services that are not accounted for in the current global trade markets in management decisions [68]. Nevertheless, promoting these restoration projects and carbon trading concepts in society itself will provide a good platform for conserving valuable ecosystems and endemic fauna and flora by providing income to the locals involved in these projects.

Nevertheless, some interesting and isolated studies conducted in different climatic zones targeting unique ecosystems were screened. One of those studies, focused on using species diversity to measure the ecosystem service conditions, showed how lichen diversity can be used as a bioindicator to measure the air quality of rural-urban ecosystems which is very significant as it demonstrates how unique species can contribute to ecosystem service management [69]. Moreover, as a country with a traditional indigenous medicinal system, Sri Lankan traditional medical practitioners have been using the vast floral biodiversity in healing processes, but we found only one published study that focused on the significance of plant biodiversity in the healing of snake bites, in which they found that 341 different plant species are utilized for traditional snakebite medication [70].

Within the assessed ecosystem services in Sri Lanka, we observed a bias towards the evaluation of regulatory and provisioning services which have clear material value compared to cultural services. This may be due to the difficulty of assessing and quantifying those cultural services [71,72]. Since these unexplored ecosystem services remain a 
significant component of the socio-ecological systems of Sri Lanka, failing to include them in studies will have negative impacts on the proper management of these ecosystems and ecosystem service benefits they provide to society.

\subsection{Present Focus of Studies on Man-Made, Agriculturally Important Ecosystems and Ecosystem Services}

One of the most rapidly emerging threats to food and livelihoods is the loss of biodiversity from traditionally species-rich agroecosystems [65] due to development projects, increased monoculture, and urbanization. However, these significant changes often go unnoticed because conventional conservation efforts repeatedly focus on endemic or charismatic species and intact ecosystems [73].

In order to assess the present focus of the published studies related to these ecosystems and services they provide and to identify drivers, pressures, and gaps that have an impact on them, we focused on two selected ecosystems in detail that are significant to Sri Lanka economically and rurally.

\subsection{Paddy Ecosystems}

Though Sri Lanka is an agriculture-based country, only a few published articles have focused on this. Soil ecosystem service is an important ecosystem service that agricultural civilizations heavily depend on [74]. However, research on how soil ecosystems are related to agriculture and food production in Sri Lanka is rare. The few studies we encountered are mostly focused on paddy cultivation $[75,76]$.

While rice is the staple food in Sri Lanka, we found only a few studies related to rice fields, and these studies were about water quality, nutrient loss, rice production, and soil quality [25,77-82]. Very little research of an interdisciplinary nature was conducted regarding paddies in Sri Lanka $[75,83]$ yet the main income for most rural farmers is rice production.

\subsection{Home Gardens}

Another important ecosystem when mentioning food provisioning services in Sri Lanka is home gardens as they provide food security throughout the year at a low cost while providing numerous other ecosystem services [84]. Though Eskil Mattsson, Ostwald and Nissanka, 2013 [85] mentioned that the current estimation of home garden distribution in Sri Lanka is $15 \%$ of the land area, almost every home in Sri Lanka has some form of a home garden, either small or large, to self-provide some of the daily utilized food items. Many of the published studies on Sri Lankan home gardens are confined to upcountry or Kandyan home gardens and are focused on few specific ecosystem services they provide [83-87]. Most have extensively focused on carbon storage [84-86]. We only encountered three studies related to the biodiversity investigation of home gardens in Sri Lanka. Among them $[86,88,89]$ few studies addressed the ecosystem services provided by home garden systems except the study from [90] on carbon storage in the dry zone home gardens. None of the other studies focused on dry zones or investigated the extent of home gardens on biodiversity conservation in different locations and in different climatic zones of the country, which we suggest and encourage to expand to every climatic zone so that a valuable addition of the flora and fauna associated with Sri Lankan home gardens could be added to the scientific community, thus enhancing their conservation opportunities.

\subsection{Significance of Ecosystem Service and Biodiversity Studies for Decision Making}

For a developing country like Sri Lanka, development projects are crucial and inevitable, as set out in the National Physical Plan 2011-2030 [33]. However, many projects are started without a proper environmental impact assessment due to various reasons including political interferences, and the harm posed on less disturbed ecosystems is massive. To show this appealingly for the decision makers it should be backed up with strong scientific evidence. Moreover, to support environmental management policies, ecosystem studies should also focus on biophysical and economic indicators integrating data and 
information with socio-economic system components and the societal and policy contexts in which they are rooted. Quantification of ecosystem services using these methods is significant not only in the proper management of ecosystems but also in the right decisions and policy formulation. However, in many circumstances transferring the outcomes of the biophysical assessments to decision making are not upfront and requires further work and a strong voice to communicate to the right audience.

Moreover, ecosystem management methods should maximize the production of one ecosystem service without declining provision of other ecosystem services, therefore future research should aim to understand the relationships among multiple ecosystem services and the mechanisms behind these relationships to improve our ability to sustainably manage ecosystems. According to Gunatilleke, 2015 [33], it is challenging to redefine the vision for the management of Sri Lanka's ecosystems to achieve sustainable development goals and to build the necessary in-country capacity to demonstrate its benefits to policymakers. To reach a responsible greener economy, well-planned integrated ecosystem service studies covering all the climatic zones of the country should be an economic and research priority.

Moreover, corrective actions for rapidly diminishing ecosystems and related services should be a priority in any environmental upgrading plans and should assign full protection to any ecosystem and area wherever it is needed. Additionally, society should also be strengthened in the conservation of ecosystems by communicating, updating, and providing understanding at all policy-making and decision-making levels in the government, business enterprises, educational institutions, and general public. This can be done by prioritizing and incorporating ecosystem and biodiversity conservation into the national planning process. Considering the diverse cultural and religious aspects of Sri Lankan society, the best approach to protect its ecosystems is by implementing a more participatory approach, considering local needs and national priorities [15].

\subsection{Future Perspectives for Sri Lankan Ecosystem Service and Biodiversity Studies}

Our results show that there is an urgent necessity to evaluate diverse ecosystems across the country, the ecosystem services they provide, and the biodiversity they harbor, as Sri Lanka is situated in a politically and economically important strategic location, attracting new investors from around the world and implementing new development projects without proper environmental impact assessments. Therefore, this existing gap of knowledge on highly diverse ecosystems across the country should be bridged with the help of experts and committed personnel by building multi-disciplinary teams, referring to existing frameworks for guidance, and drawing on the right resources.

The results obtained from this literature review strongly suggest that ecosystem service assessments and the management of those ecosystems are mostly hindered by the relative availability of published articles and conducted research with unpublished studies containing information on ecosystems and biodiversity. Our review strongly points out that studies investigating how cultural, provisioning, and regulating services are intertwined, and the role of ecosystems in the delivery of these services, are lacking in Sri Lankan ecosystem service studies. These aspects are significant to identify management practices maximizing the potential of each ecosystem to deliver ecosystem services and to protect biodiversity.

This study demonstrates a higher frequency of studies concerning the forest and other ecosystem biodiversity or species identification. However, studies investigating and quantifying ecosystem services, pressures on ecosystems, and the management of these were few. Furthermore, studies investigating the value of ecosystem services and biodiversity to the communities or involvement of stakeholders in the development of management actions regarding the ecosystems and services are rare and need intense focus in any future study as they are significant in selecting and evaluating the possible management actions regarding each unique ecosystem of the country.

Considering these identified gaps and the extensive data requirements to assess multiple ecosystem services and to create a solid information database, it is time to consult 
experts, locals, and stakeholders as an important starting point for providing a wider picture, developing integrative assessments of ecosystems in Sri Lanka. This can be done by focusing and monitoring the collected data, adding new data to the collection, and by improving the understanding of the synergies and trade-offs between ecosystems. Moreover, it is vital to provide suggestions of ecosystem management measures that would be primarily favored by the original dwellers of the ecosystems or adjacent communities and secondarily by other stakeholders considering the common challenges they face and the connectivity of ecosystems and services these ecosystems provide, and the significant benefits communities derive from them.

As the number of studies that quantify the link between biodiversity and ecosystem services is low in the surveyed literature in this review, we suggest more focus on this aspect in future studies. Additionally, as studies on the social dimension of ecosystem services in Sri Lanka investigating indigenous knowledge, human perception, and participation in decision making are fewer, they should be promoted, prioritized, and conducted. Similarly, very few valuation studies were found and the detected valuation methodologies, the analysis of beneficiaries, and the contribution of ecosystem services to human wellbeing were understudied in all the ecosystems and ecosystem service biodiversity studies in Sri Lanka. The small number of papers that quantify the contribution of biodiversity to ecosystem services suggests an important knowledge gap that should be addressed.

\section{Conclusions}

Our study demonstrates the current state of the Sri Lankan ecosystem service studies and identifies research challenges that must be addressed for the concept of ecosystem services to better inform ecosystem management. For individual studies, ensuring that the indicators, data, and techniques used to quantify ecosystem services are well defined, justifiable, validated, and reproducible are excellent starting points to move the field forward. There is a need to better understand the diversity of ecosystem service interactions and to consider the implications of using different spatial extents to quantify services and to build multidisciplinary working teams across all the climatic zones. Though these are difficult challenges it is important to ensure that ecosystem service research is conducted in its full potential to improve management and decision making in a country like Sri Lanka with many diverse and unique ecosystems, and which is a biodiversity hotspot.

Supplementary Materials: The following are available online at https:/ / www.mdpi.com/article/10 $.3390 / \mathrm{f} 12050540$ /s1, Supplementary File S1: Summary of Ecosystem service and biodiversity studies in Sri Lanka.

Author Contributions: Conceptualization, C.S.; methodology, C.S.; software, C.S., and Y.A.A.; formal analysis, C.S., and Y.A.A.; writing — original draft preparation, C.S.; writing—review and editing, C.S., Y.A.A., I.L.W., S.T.A., S.W., and Z.O.; supervision, Z.O.; project administration, Z.O.; funding acquisition, Z.O. All authors have read and agreed to the published version of the manuscript.

Funding: This study was funded by the National Natural Science Foundation of China Key Program, grant number 71533005 .

Acknowledgments: We thank Fiona R. Worthy for language editing and Sameera Suranjan Karunarathna for providing the climatic zone map of Sri Lanka.

Conflicts of Interest: The authors declare no conflict of interest.

\section{References}

1. Wang, S.; Fu, B.; Wei, Y.; Lyle, C. Ecosystem services management: An integrated approach. Curr. Opin. Environ. Sustain. 2013, 5, 11-15. [CrossRef]

2. Corvalan, C.; Hales, S.; McMichael, A. Ecosystems and Human Well-Being: Health Synthesis: A Report of the Millennium Ecosystem Assessment; Millennium Ecosystem Assessment: Geneva, Switzerland, 2005.

3. Peh, K.S.-H.; Balmford, A.; Bradbury, R.B.; Brown, C.; Butchart, S.H.; Hughes, F.M.; Stattersfield, A.; Thomas, D.H.; Walpole, M.; Bayliss, J.; et al. TESSA: A toolkit for rapid assessment of ecosystem services at sites of biodiversity conservation importance. Ecosyst. Serv. 2013, 5, 51-57. [CrossRef] 
4. Perrings, C. Biodiversity, Ecosystem Services, and Climate Change. Econ. Probl. 2010, 120, 39.

5. Awasthi, A.; Singh, K.; O'Grady, A.; Courtney, R.; Kalra, A.; Singh, R.P.; Cerdà, A.; Steinberger, Y.; Patra, D. Designer ecosystems: A solution for the conservation-exploitation dilemma. Ecol. Eng. 2016, 93, 73-75. [CrossRef]

6. Martínez-Valderrama, J.; Ibáñez, J.; Del Barrio, G.; Sanjuán, M.E.; Alcalá, F.J.; Martínez-Vicente, S.; Ruiz, A.; Puigdefábregas, J. Present and future of desertification in Spain: Implementation of a surveillance system to prevent land degradation. Sci. Total. Environ. 2016, 563, 169-178. [CrossRef] [PubMed]

7. Knapp, W.M.; Frances, A.; Noss, R.; Naczi, R.F.C.; Weakley, A.; Gann, G.D.; Baldwin, B.G.; Miller, J.; McIntyre, P.; Mishler, B.D.; et al. Vascular plant extinction in the continental United States and Canada. Conserv. Biol. 2021, 35, $360-368$. [CrossRef] [PubMed]

8. Le Roux, J.J.; Hui, C.; Castillo, M.L.; Iriondo, J.M.; Keet, J.-H.; Khapugin, A.A.; Médail, F.; Rejmánek, M.; Theron, G.; Yannelli, F.A.; et al. Recent Anthropogenic Plant Extinctions Differ in Biodiversity Hotspots and Coldspots. Curr. Biol. 2019, 29, 2912-2918. [CrossRef]

9. Khapugin, A.A.; Kuzmin, I.V.; Silaeva, T.B. Anthropogenic drivers leading to regional extinction of threatened plants: Insights from regional Red Data Books of Russia. Biodivers. Conserv. 2020, 29, 2765-2777. [CrossRef]

10. Burkhard, B.; Maes, J. Mapping Ecosystem Services; Pensoft Publishers: Sofia, Bulgaria, 2017; Volume 42.

11. Xiaoqing, Z.; Zexian, G.; Xiangyu, G. Land use and land-cover change and its impact on ecosystem services values in a region with large-area artificial gardens. Resour. Environ. Yangtze Basin 2016, 25, 88-97.

12. Gardner, T.A.; Barlow, J.; Chazdon, R.; Ewers, R.M.; Harvey, C.A.; Peres, C.A.; Sodhi, N.S. Prospects for tropical forest biodiversity in a human-modified world. Ecol. Lett. 2009, 12, 561-582. [CrossRef] [PubMed]

13. Balmford, A.; Bruner, A.; Cooper, P.; Costanza, R.; Farber, S.; Green, R.E.; Jenkins, M.; Jefferiss, P.; Jessamy, V.; Madden, J.; et al. Economic Reasons for Conserving Wild Nature. Science 2002, 297, 950-953. [CrossRef] [PubMed]

14. Foley, J.A.; Costa, M.H.; Delire, C.; Ramankutty, N.; Snyder, P. Green surprise? How terrestrial ecosystems could affect earth's climate. Front. Ecol. Environ. 2003, 1, 38-44.

15. Ranasinghe, D.M.S.H.K. Biodiversity; What are we losing? a case on Sri Lanka. In Proceedings of the 2nd International Interdisciplinary Conference on the Environment, Newport, RI, USA, 15-20 June 1996; pp. 248-258.

16. Bossuyt, F.; Meegaskumbura, M.; Beenaerts, N.; Gower, D.J.; Pethiyagoda, R.; Roelants, K.; Mannaert, A.; Wilkinson, M.; Bahir, M.M.; Manamendra-Arachchi, K.; et al. Local Endemism Within the Western Ghats-Sri Lanka Biodiversity Hotspot. Science 2004, 306, 479-481. [CrossRef] [PubMed]

17. Helgen, K.M. Family Castoridae. In Mammal Species of the World, 3rd ed.; Wilson, D.M., Reeder, D.E., Eds.; The Johns Hopkins University Press: Baltimore, MD, USA, 2005; pp. 842-843.

18. Mulverhill, C.; Coops, N.C.; White, J.C.; Tompalski, P.; Marshall, P.L.; Bailey, T. Enhancing the Estimation of Stem-Size Distributions for Unimodal and Bimodal Stands in a Boreal Mixedwood Forest with Airborne Laser Scanning Data. Forests 2018,9 , 95. [CrossRef]

19. Domroes, M. Monsoon and land use in Sri Lanka. GeoJournal 1979, 3, 179-192. [CrossRef]

20. Marambe, B.; Punyawardena, R.; Silva, P.; Premalal, S.; Rathnabharathie, V.; Kekulandala, B.; Nidumolu, U.; Howden, M. Climate, climate risk, and food security in Sri Lanka: Need for strengthening adaptation strategies. In Handbook of Climate Change Adaptation; Springer: Berlin/Heidelberg, Germany, 2015; pp. 1759-1789.

21. Jayawardena, D. The Present Status of the Development of Mineral Resources. J. Natn. Sci. Coun. Sri Lanka 1984, $12,53-69$.

22. Pitawala, H.M.T.G.A. Mineralogy, petrography, geochemistry and economic potential of carbonate rocks of Sri Lanka. J. Geol. Soc. Sri Lanka 2019, 20, 1-13. [CrossRef]

23. Zubair, L.; Nissanka, S.P.; Weerakoon, W.M.W.; Herath, D.I.; Karunaratne, A.S.; Prabodha, A.S.M.; Agalawatte, M.B.; Herath, R.M.; Yahiya, S.Z.; Punyawardhene, B.V.R.; et al. Climate Change Impacts on Rice Farming Systems in Northwestern Sri Lanka. In Handbook of Climate Change and Agroecosystems; Rosenzweig, C., Hillel, D., Eds.; World Scientific Publishing: Singapore, 2015; pp. 315-352.

24. Gunawardena, A.; Fernando, T.; Takeuchi, W.; Wickramasinghe, C.H.; Samarakoon, L. Identification, evaluation and change detection of highly sensitive wetlands in South-Eastern Sri Lanka using ALOS (AVNIR2, PALSAR) and Landsat ETM+ data. In Proceedings of the 7th IGRSM International Remote Sensing and GIS Conference and Exhibition, Kuala Lumpur, Malaysia, 21-22 April 2014; Volume 20, pp. 21-23.

25. Illukpitiya, P.; Shanmugaratnam, N.; Kjosavik, D.J. Tea Agroecosystems in the Uva Highlands of Sri Lanka. Mt. Res. Dev. 2004, 24, 52-59. [CrossRef]

26. Näsström, R.; Mattsson, E. Country Report Sri Lanka: Land-Use Change and Forestry at the National and Sub-National Level; Focali Report; University of Gothenburg: Gothenburg, Sweden, 2011.

27. FAO. Global Forest Resources Assessment 2010; FAO: Rome, Italy, 2010.

28. Ranagalage, M.; Gunarathna, M.H.J.P.; Surasinghe, T.D.; Dissanayake, D.; Simwanda, M.; Murayama, Y.; Morimoto, T.; Phiri, D.; Nyirenda, V.R.; Premakantha, K.T.; et al. Multi-Decadal Forest-Cover Dynamics in the Tropical Realm: Past Trends and Policy Insights for Forest Conservation in Dry Zone of Sri Lanka. Forrests 2020, 11, 836. [CrossRef]

29. WDPA. World Database on Protected Areas Consortium; WDPA: Cambridge, UK, 2015. 
30. Sarathchandra, C.; Kambach, S.; Ariyarathna, S.C.; Xu, J.; Harrison, R.D.; Wickramasinghe, S. Significance of Mangrove Biodiversity Conservation in Fishery Production and Living Conditions of Coastal Communities in Sri Lanka. Diversity 2018, 10, 20. [CrossRef]

31. Sellapperumage, S. Fighting Deforestation in Sri Lanka. Asia Life, 23 October 2020.

32. Rathnayake, C.W.; Jones, S.; Soto-Berelov, M. Mapping Land Cover Change over a 25-Year Period (1993-2018) in Sri Lanka Using Landsat Time-Series. Land 2020, 9, 27. [CrossRef]

33. Gunatilleke, N. Forest sector in a green economy: A paradigm shift in global trends and national planning in Sri Lanka. J. Natl. Sci. Found. Sri Lanka 2015, 43, 101-109. [CrossRef]

34. Perera, K.; De Silva, K.; Amarasinghe, M. Potential impact of predicted sea level rise on carbon sink function of mangrove ecosystems with special reference to Negombo estuary, Sri Lanka. Glob. Planet. Chang. 2018, 161, 162-171. [CrossRef]

35. Langmaier, M.; Lapin, K. A Systematic Review of the Impact of Invasive Alien Plants on Forest Regeneration in European Temperate Forests. Front. Plant Sci. 2020, 11, 1-15. [CrossRef]

36. R Core Team. R: A Language and Environment for Statistical Computing; R Foundation for Statistical Computing: Austria, Vienna, 2016.

37. Dayaratne, P.; Linden, O.; de Silva, M.W.R.N. Puttalam Lagoon and Mundel Lake, Sri Lanka: A study of coastal resources: Their utilisation, environmental issues and management options. Ambio 1995, 24, 391-401.

38. Kodikara, K.A.S.K.; Mukherjee, N.; Jayatissa, L.P.; Dahdouh-Guebas, F.; Koedam, N. Have mangrove restoration projects worked? An in-depth study in Sri Lanka. Restor. Ecol. 2017, 25, 705-716. [CrossRef]

39. Hettiarachchi, M.; Morrison, T.H.; Wickramsinghe, D.; Mapa, R.; de Alwis, A.; Mcalpine, C.A. Landscape and Urban Planning The eco-social transformation of urban wetlands: A case study of Colombo, Sri Lanka. Landsc. Urban Plan. 2014, 132, 55-68. [CrossRef]

40. Bournazel, J.; Kumara, M.P.; Jayatissa, L.P.; Viergever, K.; Morel, V.; Huxham, M. Ocean \& Coastal Management The impacts of shrimp farming on land-use and carbon storage around Puttalam lagoon, Sri Lanka. Ocean Coast. Manag. 2015, 113, 18-28.

41. Gunawardena, A.; White, B.; Hailu, A.; Wijeratne, E.; Pandit, R. Policy choice and riverine water quality in developing countries: An integrated hydro-economic modelling approach. J. Environ. Manag. 2018, 227, 44-54. [CrossRef] [PubMed]

42. Bergquist, D.A. Sustainability and Local People's Participation in Coastal Aquaculture: Regional Differences and Historical Experiences in Sri Lanka and the Philippines. Environ. Manag. 2007, 40, 787-802. [CrossRef]

43. McInnes, R.J.; Everard, M. Rapid Assessment of Wetland Ecosystem Services (RAWES): An example from Colombo, Sri Lanka. Ecosyst. Serv. 2017, 25, 89-105. [CrossRef]

44. Gunawardena, A.; Wijeratne, E.M.S.; White, B.; Hailu, A.; Pandit, R. Industrial pollution and the management of river water quality: A model of Kelani River, Sri Lanka. Environ. Monit. Assess. 2017, 189, 457. [CrossRef] [PubMed]

45. De Silva, M.; de Silva, P.K. Status, diversity and conservation of the mangrove forests of Sri Lanka. J. South Asian Nat. Hist. 1998, 3, 79-102.

46. Senarath, U.; Visvanathan, C. Environmental issues in brackish water shrimp aquaculture in Sri Lanka. Environ. Manag. 2001, 27, 335-348. [CrossRef] [PubMed]

47. Gunawardena, M.; Rowan, J.S. Economic Valuation of a Mangrove Ecosystem Threatened by Shrimp Aquaculture in Sri Lanka. Environ. Manag. 2005, 36, 535-550. [CrossRef]

48. Amarasinghe, M.D.; Balasubramaniam, S. Structural properties of two types of mangrove stands on the northwestern coast of Sri Lanka. Hydrobiologia 1992, 247, 17-27. [CrossRef]

49. Jayathilake, M.B.; Chandrasekara, W.U. Variation of avifaunal diversity in relation to land-use modi fi cations around a tropical estuary, the Negombo estuary in Sri Lanka. J. Asia-Pacific Biodivers. 2015, 8, 72-82. [CrossRef]

50. Karunarathna, S.; Amarasinghe, A.A.T.; Henkanaththegedara, S.; Surasinghe, T.; Madawala, M.; Gabadage, D.; Botejue, M. Distribution, habitat associations and conservation implications of Sri Lankan freshwater terrapins outside the protected area network. Aquat. Conserv. Mar. Freshw. Ecosyst. 2017, 27, 1301-1312. [CrossRef]

51. Gunatilake, H.M.; Senaratne, D.M.A.H.; Abeygunawardena, P. Role of non-timber forest products in the economy of peripheral communities of knuckles national wilderness area of Sri Lanka: A farming systems approach. Econ. Bot. 1993, 47, $275-281$. [CrossRef]

52. Dhakal, B.; Pinard, M.A.; Gunatilleke, I.N.; Gunatilleke, C.S.; Weerasinghe, H.M.; Dharmaparakrama, A.L.S.; Burslem, D.F. Forest Ecology and Management Impacts of cardamom cultivation on montane forest ecosystems in Sri Lanka. For. Ecol. Manag. 2012, 274, 151-160. [CrossRef]

53. Batuwita, S.; Udugampala, S. Description of a new species of Cnemaspis (Squamata: Gekkonidae) from Knuckles Range of Sri Lanka. Zootaxa 2017, 4254, 82-90. [CrossRef] [PubMed]

54. Edirisinghe, G.; Surasinghe, T.; Gabadage, D.; Botejue, M.; Perera, K.; Madawala, M.; Weerakoon, D.; Karunarathna, S. Chiropteran diversity in the peripheral areas of the Maduru-Oya National Park in Sri Lanka: Insights for conservation and management. ZooKeys 2018, 784, 139-162. [CrossRef]

55. Gabadage, D.E.; Botejue, W.M.S.; Surasinghe, T.D.; Bahir, M.M.; Madawala, M.B.; Dayananda, B.; Weeratungae, V.U.; Karunarathnaf, S. Biodiversity Avifaunal diversity in the peripheral areas of the Maduruoya National Park in Sri Lanka: With conservation and management implications. J. Asia-Pacific Biodivers. 2015, 8, 121-132. [CrossRef] 
56. Gamage, S.; Weerakoon, D.; Gunawardena, A. Current status of vertebrate diversity in anthropogenic and natural ecosystems in south-western Sri Lanka. J. Natl. Sci. Found. Sri Lanka 2011, 39, 383. [CrossRef]

57. Goodale, E.; Kotagama, S.W.; Raman, T.S.; Sidhu, S.; Goodale, U.M.; Parker, S.; Chen, J. The response of birds and mixed-species bird flocks to human-modified landscapes in Sri Lanka and southern India. For. Ecol. Manag. 2014, 329, 384-392. [CrossRef]

58. Gunatilleke, I.A.U.N.; Gunatilleke, C.V.S.; Dilhan, M.A.A.B. Plant biogeography and conservation of the south-western hill forests of Sri Lanka. Raffles Bull. Zool. 2005, 12, 9-22.

59. Gunawardene, N.R.; Daniels, A.E.; Gunatilleke, I.A.U.N.; Gunatilleke, C.V.S.; Karunakaran, P.V.; Nayak, K.G.; Prasad, S.; Puyravaud, P.; Ramesh, B.R.; Subramanian, K.A.; et al. A brief overview of the Western Ghats-Sri Lanka biodiversity hotspot. Curr. Sci. 2007, 93, 1567-1572.

60. Karunarathna, S.; Bauer, A.M.; De Silva, A.; Surasinghe, T.; Somaratna, L.; Madawala, M.; Gabadage, D.; Botejue, M.; Henkanaththegedara, S.; Ukuwela, K.D. Description of a new species of the genus Cnemaspis Strauch, 1887 (Reptilia: Squamata: Gekkonidae) from the Nilgala Savannah forest, Uva Province of Sri Lanka. Zootaxa 2019, 4545, 389-407. [CrossRef] [PubMed]

61. Karunarathna, S.; Poyarkov, N.A.; De Silva, A.; Madawala, M.; Botejue, M.; Gorin, V.A.; Surasinghe, T.; Gabadage, D.; Ukuwela, K.D.B.; Bauer, A.M. Integrative taxonomy reveals six new species of day geckos of the genus Cnemaspis Strauch, 1887 (Reptilia: Squamata: Gekkonidae) from geographically-isolated hill forests in Sri Lanka. Vertebr. Zool. 2019, 69, 247-298.

62. Kudavidanage, E.P.; Qie, L.; Lee, J.S.H. Linking biodiversity and ecosystem functioning of dung beetles in South and South East Asian tropical rainforests. Raffles Bull. Zool. 2012, 25, 133-146.

63. Ginige, A.; De Silva, L.; Ginige, T.; Pasquale, D.G.; Walisadeera, A.; Mathai, M.; Goonetillake, J.; Wikramanayake, G.; Vitiello, G.; Sebillo, M. Towards an Agriculture Knowledge Ecosystem: A Social Life Network for Farmers in Sri Lanka. In Proceedings of the 9th Conference of the Asian Federation for Information Technology in Agriculture: ICTs for Future Economic and Sustainable Agricultural Systems, Perth, Australia, 29 September-2 October 2014; pp. 170-179.

64. Gunatilleke, I.A.U.N.; Gunatilleke, C.V.S.; Abeygunawardena, P. Interdisciplinary research towards management of non-timber forest resources in lowland rain forests of Sri Lanka. Econ. Bot. 1993, 47, 282-290. [CrossRef]

65. Subasinghe, K.; Sumanapala, A.P.; Weerawardhena, S.R. The impact of forest conversion on bird communities in the northern fl ank of the Knuckles Mountain Forest Range, Sri Lanka. J. Asia-Pacific Biodivers. 2014, 7, 367-373. [CrossRef]

66. Pethiyagoda, R. Biodiversity conservation in Sri Lanka's novel ecosystems. Ceylon J. Sci. 2012, 41, 1-10. [CrossRef]

67. Senadheera, D.L.; Wahala, W.; Weragoda, S. Livelihood and ecosystem benefits of carbon credits through rainforests: A case study of Hiniduma Bio-link, Sri Lanka. Ecosyst. Serv. 2019, 37, 100933. [CrossRef]

68. TEEB. The economics of ecosystems and biodiversity. In Ecological and Economic Foundations; Kumar, P., Ed.; Earthscan Publication: Washington, DC USA; London, UK, 2010; p. 2010.

69. Yatawara, M.; Dayananda, N. Use of corticolous lichens for the assessment of ambient air quality along rural-urban ecosystems of tropics: A study in Sri Lanka. Environ. Monit. Assess. 2019, 191, 179. [CrossRef]

70. Dharmadasa, R.; Akalanka, G.; Muthukumarana, P.; Wijesekara, R. Ethnopharmacological survey on medicinal plants used in snakebite treatments in Western and Sabaragamuwa provinces in Sri Lanka. J. Ethnopharmacol. 2016, 179, 110-127. [CrossRef] [PubMed]

71. Hanna, D.E.L.; Tomscha, S.A.; Dallaire, C.O.; Bennett, E.M. A review of riverine ecosystem service quantification: Research gaps and recommendations. J. Appl. Ecol. 2018, 55, 1299-1311. [CrossRef]

72. Chan, K.M.A.; Guerry, A.D.; Balvanera, P.; Klain, S.; Satterfield, T.; Basurto, X.; Bostrom, A.; Chuenpagdee, R.; Gould, R.K.; Halpern, B.S.; et al. Where are Cultural and Social in Ecosystem Services? A Framework for Constructive Engagement. BioScience 2012, 62, 744-756. [CrossRef]

73. Balzan, M.V.; Potschin-Young, M.; Haines-Young, R. Island ecosystem services: Insights from a literature review on case-study island ecosystem services and future prospects. Int. J. Biodivers. Sci. Ecosyst. Serv. Manag. 2018, 14, 71-90. [CrossRef]

74. Baveye, P.C.; Baveye, J.; Gowdy, J. Soil 'ecosystem' services and natural capital: Critical appraisal of research on uncertain ground. Front. Environ. Sci. 2016, 4, 1-49. [CrossRef]

75. Hewawasam, T.; Illangasinghe, S. Quantifying sheet erosion in agricultural highlands of Sri Lanka by tracking grain-size distributions. Anthropocene 2015, 11, 25-34. [CrossRef]

76. Ratnayake, R.; Seneviratne, G.; Kulasooriya, S. Effects of land use and management practices on quantitative changes of soil carbohydrates. J. Natl. Sci. Found. Sri Lanka 2011, 39, 345-353. [CrossRef]

77. Dharmasena, P.B. Assessment of Traditional Rice Farming: A Case Study from Moneragala District of Sri Lanka. Badulla: Future in Our Hand Development Fund. 2010. Available online: https://www.researchgate.net/profile/Punchi-Bandage-Dharmasena/ publication/303994626_Assessment_of_Traditional_Rice_Farming_A_Case_Study_from_Moneragala_District_of_Sri_Lanka/ links/5762245908aeeada5bc5064a / Assessment-of-Traditional-Rice-Farming-A-Case-Study-from-Moneragala-District-of-SriLanka.pdf (accessed on 20 March 2021).

78. Weerasinghe, K.; Basnayake, S.; Arambepola, N.; Rathnayake, U.; Nawaratne, C. A Local Level Technology and Policy Intervention Approach to Restore Paddy Ecosystems in the Nilwala Downstream, Affected due to Nilwala Flood Protection Scheme, Southern Sri Lanka. Procedia Econ. Finance 2014, 18, 336-344. [CrossRef]

79. Balasooriya, W.K.; Huygens, D.; Rajapaksha, R.; Boeckx, P. Effect of rice variety and fertilizer type on the active microbial community structure in tropical paddy fields in Sri Lanka. Geoderma 2016, 265, 87-95. [CrossRef] 
80. Bambaradeniya, C.N.B.; Edirisinghe, J.P.; De Silva, D.N.; Gunatilleke, C.V.S.; Ranawana, K.B.; Wijekoon, S. Biodiversity associated with an irrigated rice agro-ecosystem in Sri Lanka. Biodivers. Conserv. 2004, 13, 1715-1753. [CrossRef]

81. Chambers, R. Water Management and Paddy Production in the Dry Zone of Sri Lanka; Agrarian Research \& Training Institute: Colombo, Sri Lanka, 1975.

82. Stone, E.C.; Hornberger, G.M. Impacts of management alternatives on rice yield and nitrogen losses to the environment: A case study in rural Sri Lanka. Sci. Total. Environ. 2016, 542, 271-276. [CrossRef]

83. Horgan, F.G.; Kudavidanage, E.P.; Weragodaarachchi, A.; Ramp, D. Traditional 'maavee' rice production in Sri Lanka: Environmental, economic and social pressures revealed through stakeholder interviews. Paddy Water Environ. 2017, 16, 225-241. [CrossRef]

84. Mattsson, E.; Ostwald, M.; Nissanka, S.P. What is good about Sri Lankan homegardens with regards to food security? A synthesis of the current scientific knowledge of a multifunctional land-use system. Agrofor. Syst. 2018, 92, 1469-1484. [CrossRef]

85. Mattsson, E.; Ostwald, M.; Nissanka, S.P.; Marambe, B. Homegardens as a Multi-functional Land-Use Strategy in Sri Lanka with Focus on Carbon Sequestration. Ambio 2013, 42, 892-902. [CrossRef]

86. Mattsson, E.; Ostwald, M.; Nissanka, S.P.; Pushpakumara, D.K.N.G. Quantification of carbon stock and tree diversity of homegardens in a dry zone area of Moneragala district, Sri Lanka. Agrofor. Syst. 2014, 89, 435-445. [CrossRef]

87. Mohri, H.; Lahoti, S.; Saito, O.; Mahalingam, A.; Gunatilleke, N.; Irham; Hoang, V.T.; Hitinayake, G.; Takeuchi, K.; Herath, S. Assessment of ecosystem services in homegarden systems in Indonesia, Sri Lanka, and Vietnam. Ecosyst. Serv. 2013, 5, 124-136. [CrossRef]

88. Pushpakumara, D.K.N.G.; Wijesekara, A.; Hunter, D.G. Sustainable Use of Biological Diversity in Socio-Ecological Production Landscapes. In Background to the 'Satoyama Initiative for the Benefit of Biodiversity and Human Well-Being; Secretariat of the Convention on Biological Diversity: Montreal, Canada, 2010.

89. Hitinayake, H.M.G.S.B.; Ekanayake, U. Utilization of underutilized fruit tree species grown in Kandyan home gardens. In Proceedings of the Tenth National Workshop on Multipurpose Trees: Fruit for the Future, Kandy, Sri Lanka, 5 November 1999; pp. 252-264.

90. Ali, A.; Mattsson, E. Individual tree size inequality enhances aboveground biomass in homegarden agroforestry systems in the dry zone of Sri Lanka. Sci. Total. Environ. 2017, 575, 6-11. [CrossRef] 